\title{
LUDIC REPRESENTATIONS OF NURSING TECHNICIANS ABOUT THE SYSTEMATIZATION OF NURSING CARE
}

\author{
REPRESENTAÇÕES LÚDICAS DE TÉCNICOS DE ENFERMAGEM ACERCA DA \\ SISTEMATIZAÇÃO DA ASSISTENNCIA DE ENFERMAGEM
}

\author{
Pétala Tuani Candido de Oliveira SALVADOR ${ }^{1}$; Viviane Euzébia Pereira SANTOS ${ }^{1}$ \\ 1. Programa de pós-graduação em Enfermagem, Universidade Federal do Rio Grande do Norte, Natal, RN, Brasil. \\ petalatuani@hotmail.com
}

\begin{abstract}
The objective was to describing the ludic representations of nursing technicians about the Systematization of Nursing Care. This is a clipping of a phenomenological investigation results. The data were collected from a focus group with thirteen nursing technicians, using the construction of projective technique, based on the principles of Experiential Humanescent Pedagogy. The data analysis was carried out from guiding principles based on the work of Alfred Schutz. The ludic representation of nursing technical architects perpassed four thematic axes: Systematization of Nursing Care concept; benefits; problems experienced; and needs for improvement. It is concluded that nursing technicians represent positively the Systematization of Nursing Care, and believe in its consolidation. It is stressed that the use of the construction of billboards as projective technique constitutes an element qualifier of the study by stimulating the expression of subjectivities of the subjects surveyed.
\end{abstract}

KEYWORDS: Education. Nursing. Associate. Nurses’ Aides. Patient Care Planning. Nursing Process.

\section{INTRODUCTION}

The nursing technician (NT), according to the law of the professional practice of nursing-law $\mathrm{n}^{\mathrm{o}} 7,498 / 1986$, is the component of the nursing staff that carries middle-level activities, involving both the guidance and monitoring of nursing work in auxiliary grade running assistance actions, as participation in the planning of nursing care (BRASIL, 1986).

This is a professional who carries out activities that are essential to ensuring the effectiveness of nursing care, representing the professional category with the most numerous within the quantitative nursing staff (COFEN, 2011).

Thus it is recognized the imperativeness of integration of the Systematization of Nursing Care, which is defended legally by resolution No. $358 / 2009$, of the Federal Council of Nursing Care (COFEN), which states that the nursing technician should participate in the implementation of the nursing process - one of the tools of solidification of the ideals of the Systematization of Nursing Care - that they fit under the supervision and guidance of the nurse (COFEN, 2009).

However, admittedly NT participation in Systematization of Nursing Care is still seen as an obscure field, involving multiple obstacles, such as: the NT, in general, collaborates in a limited way, being his involvement with the Systematization of Nursing Care restricted in most cases to achieve the prescribed nursing care, neglecting their contributions with the action planning; the nurse seems to ignore the skills of NT related to exercise of Systematization of Nursing Care, disabling the important partnership of NT; and, still, NT show little knowledge about the methodology employed, with little or no information is given during the training of mid-level professionals about the Systematization of Nursing Care (CRUZ; ALMEIDA, 2010; RAMOS; CARVALHO; CANINI, 2009).

Furthermore, it is important to highlight the difficulties of this category in relation to the workload, compensation, preparing to engage in particular activities and knowledge or views on the theme discussed, aspects that strongly characterize the dynamics of nursing technicians in general assistance and their training and preparation in Brazilian health institutions.

To overcome such obstacles is therefore a fundamental aspect, since it understands that the integration of the various categories of nursing in realization of Systematization of Nursing Care, complied with the legal requirements, consists of sine qua non strategy to overcome barriers of operationalization of this method (RAMOS; CARVALHO; CANINI, 2009).

Also, it is argued that the contribution of the NT can expand and strengthen the assumptions of Systematization of Nursing Care, collaborating with a team more critical and reflective (CRUZ; ALMEIDA, 2010), strengthening nursing as a 
Ludic representations of nursing...

science of caring, based on binomial thinking-do, without which the nursing actions to reduce spontaneous practices, lacking in clinical reasoning.

In this context, it is understood that investigate professional perceptions about the Systematization of Nursing Care can help to identify whether there are gaps in understanding of these professionals, as well as to understand the vision of the same about this working method, considering that the belief or disbelief in the positivity of the Systematization of Nursing Care can influence the motivation of the trader to execute it.

So, it was presented as a question of this research: As nursing technicians understand the Systematization of Nursing Care? Thus, the goal of this work was to describe the playful representations of nursing technicians about the Systematization of Nursing Care.

\section{MATERIAL AND METHODS}

The study in a screen constitutes a clipping of the results obtained from the dissertation entitled "Understanding the typical ideal of nursing technicians about the systematization of nursing care", developed by the postgraduate program in nursing at the Federal University of Rio Grande do Norte (UFRN).

The meeting was held on February $15^{\text {th }}$, 2013 , in a previously prepared room on the $4^{\text {th }}$ HUOL underground, totaling 101 minutes, with the collaboration of thirteen nursing technicians.

It is a phenomenological investigation, carried out in the light of the theoretical framework of Alfred Schutz. For data collection, we used the focal group technique, which consists of a quick, low-cost technique for assessing and obtaining data and qualitative information, identifying feelings, attitudes and ideas of the participants about a particular subject or activity (MINAYO, 2010).

The focal group, titled "What I think about Systematization of Nursing Care", was conducted in accordance with the Experiential Humanescent Pedagogy (EHP - being called in English language): transcorporal humanescent pedagogical reality based on knowledge from within the Being, of his human abilities, their subjectivity and their corporality, from playfulness (CAVALCANTI, 2010).

The pedagogical process based on EHP promotes, as well, in the sphere of education, the learning through work with the imaginary, valuing the previous knowledge, the course and the pace of construction of each individual, encouraging
SALVADOR, P. T. C. O.; SANTOS, V. E. P.

reflection and creativity (CAVALCANTI, 2010). Guides, therefore, by playful representations.

Thus, this design had the scope for facilitating the expression of the motivations of the subjects. It was employed, in this context, the construction of posters, using the figurative representation, by means of miniatures, crayons, pens and stickers, to seize NTs' perceptions about the Systematization of Nursing Care, associating the represent, compose and share reflections as a means to facilitate the identification of playful representation of NTs, from the key question: What is systematization of nursing care for you?

It is stresses that the use of projective techniques contributes to an investigation of unconscious content, promotes dialogue and creates a favorable environment for research of subjective aspects not revealed in verbalization, stimulating the expression of feelings, being consistent, therefore, with the ideals of the focal group (GREJANIN et al., 2007; SOUSA et al., 2010).

The proposal was, then, in use the triad "mount-talk-write" to stimulate the expression of the perceptions of the participants about the guiding question: 1) assemble a poster using the materials provided; 2) talk about their representations, sharing ideas and opinions; and 3) write the description of the scenario built in a research instrument that contributed to the analysis of the speeches of NT.

Told with the collaboration of thirteen nursing technicians active at University Hospital Onofre Lopes (HUOL), Natal, Rio Grande do Norte, which responded positively to the following inclusion criteria: acting in direct assistance care HUOL, performing to patients. The amount of sample was defined based on the optimal number of subjects who must compose a focal group, ensuring the effective participation of all (MINAYO, 2010).

In order to understand a little who were the NT, was applied at the beginning of the meeting, a questionnaire to participants of the study, composed of closed questions and divided into two parts: socio-demographic data and data professionals. From the agreement of the subject, the focal group was recorded and photographed, counting on the cooperation of a rapporteur, who noted that that cannot be captured by the recordings, such as facial expressions, bodily expressions, among other aspects; and two other employees, responsible for the photographic record and support.

The study followed the ethical and legal principles governing research on humans, recommended in resolution No. 196/1996 of the National Health Council, being approved by Opinion Embodied Research Ethics Committee 
Ludic representations of nursing...

from UFRN, No. 98,424, of August $31^{\text {st }}, 2012$, CAAE $n^{\circ}$ 05906912.0.0000.5537.

The transcription was done by his own Master's student, after hearing the tapes several times, in addition to having as primary support records conducted by the Rapporteur of the focal group. Microsoft Word $^{\circledR} 2010$ was used for the realization of the transcript of the meeting and Microsoft Excel $^{\circledR} 2010$ for synthesis of results through a worksheet. Later, the transcript was shared with both the rapporteur and the contributors to the encounter, as with the subjects of research, ensuring completeness of same and the reliability of the records, which allowed have clarity that captured the essences, by qualifying the method.

The subjects are identified by the letters NT (Nursing Technician), followed by the sequential number from one to thirteen (NT1, NT2, so on, until NT13).

Finally, the lines were organized by multiple readings, which allowed, along with the analysis of the posters built, describing the ludic representations of nursing technicians about the Systematization of Nursing Care. The data analysis was based on the guiding principles (ZEFERINO, 2010) based on the work of Alfred Schutz, phenomenologist who reflects on the subjective experiences of human beings.

Stand out from the fourth, fifth and sixth guiding principles (ZEFERINO, 2010), through which the data analysis was carried out and settled the themes: fourth - postulate of subjective interpretation - when it held a clipping of lines representing the meanings of structures, proceeding with the grouping of passages expressing common reasons for the questioning, building the categories of human action that they contained the actions of individuals in relation to the meaning of the phenomenon; fifth - postulate of adequacy - in which the subject turned to the transcript of the meeting, which allowed to be clear that captured the essences, improving the method; and sixth scientific logic rationality - at which time the themes are unveiled, presenting ludic representations of nursing technicians about the Systematization of Nursing Care.

\section{RESULTS AND DISCUSSION}

The analysis of the signs, lines and records allowed describe the playful representation of NTs on the Systematization of Nursing Care, bypassing four thematic axes, which emerged from multiple readings and reflections undertaken, namely:
SALVADOR, P. T. C. O.; SANTOS, V. E. P.

concept; benefits; difficulties; and possibilities for improvement.

\section{Concept of Systematization of Nursing Care: idealization of the unknown}

Despite the NTs have reported that they have graduated, on average, two years ago, a time when resolutions $272 / 2002$ and $358 / 2009$, of the COFEN, had already been published, defending the effectuation of the SNC in the context of nursing teams, they revealed that they have never had contact, nor academic nor professional, with the theme, unaware even the term "Systematization of Nursing Care".

Similarly, other investigations concerning the interface between NT and the Systematization of Nursing Care stressed that during the technical course such contact did not occur, not existing any discussion about the Systematization of Nursing Care in the academic environment of the NT (CRUZ; ALMEIDA, 2010; RAMOS; CARVALHO; CANINI, 2009).

This is an issue of concern, since it understands that, "while the knowledge about the methodology is restricted to the practice of nurses, it is unlikely that the other categories of nursing staff contribute to their recognition" (CRUZ; ALMEIDA, 2010 , p. 926) and that, consequently, the Systematization of Nursing Care is effectively consolidated.

However, despite not having had contact with the theme in their training environment, either in their desktop, eventually NTs idealize the unknown, representing what they thought about the Systematization of Nursing Care, building a concept completely beneficial and positive by expressing the subjective face of this working tool, which goes beyond the scientific concepts.

It should be noted that the method used for data collection allowed the nursing technicians reflect on the Systematization of Nursing Care subjectively, even without the formal theoretical knowledge about the theme. Thus, by using an innovative method, it was possible that this fact does not turn into a bias for the study, but the possibility of ludic representation of the theme, showing a subjective face that matches the precepts of Systematization of Nursing Care.

For it, thumbnails, stickers and drawings were used, in addition to words or even written reflections, revealing the experiences of NTs about the Systematization of Nursing Care. By means of letters and numbers, the NTs idealized Systematization of Nursing Care as a professional learning process, through which the nursing 
Ludic representations of nursing...

professionals will understand the rules and techniques specific to your care, i.e. the Systematization of Nursing Care would be the means of care, systematically, from users. Table 1 summarizes the representations of the NTs about the Systematization of Nursing Care.

In general, NTs have idealized the Systematization of Nursing Care as a tool which encourages the handle with humanescence and accountability: the flowers, representing such aspects, appeared in almost all of the posters, along with heart stickers and even the word LIFE, proving to be the object of nursing work a precious commodity that must continually be veiled.

The Systematization of Nursing Care, in this perspective, would be the system that covers the whole process of nursing care, ensuring that equal
SALVADOR, P. T. C. O.; SANTOS, V. E. P.

attention and solidifying quality, focusing on humanescence, in which the heart, in the center of the poster, would represent the wards, stage of consolidation of this working tool.

Also, the NTs seized the Systematization of Nursing Care as the professional knowledge able to organize their care, planning-to ensure that there is a parity between what you think and what you do:

"[...] I deduce it's a study, that everything works with equality, like all rights equally in health, which has a good service by health professionals and all, one day, be good as is planned on paper" (NT10).

It is idealized as a positive concept of Systematization of Nursing Care, as a process of care that would bring numerous benefits for those involved.

Table 1: Summary of the meanings of NTs about Systematization of Nursing Care, according to the lines and with the objects used, Natal/Rio Grande do Norte, 2013.

\begin{tabular}{|c|c|c|c|}
\hline Subjects & Meanings & Objects & Speeches \\
\hline $\begin{array}{c}\text { NT5, NT8, NT9, } \\
\text { NT10, NT11, } \\
\text { NT12 }\end{array}$ & $\begin{array}{l}\text { Something } \\
\text { unknown }\end{array}$ & Interrogation & $\begin{array}{l}\text { Systematization of nursing care, for me, I } \\
\text { don't have much idea what is [...] (NT5) } \\
\text { I never understood to tell the truth [...] } \\
\text { (NT10) } \\
\text { I can tell everyone that, really, I don't } \\
\text { have any explanation on systematization } \\
\text { (NT11) } \\
\text { Actually, I'll speak for loud, because I do } \\
\text { not understand of systematization (NT12) }\end{array}$ \\
\hline NT1, NT7, NT9 & $\begin{array}{l}\text { System that } \\
\text { constitutes } \\
\text { nursing }\end{array}$ & $\begin{array}{l}\text { Representation of } \\
\text { flowers, from the illness } \\
\text { until their renewal } \\
\text { (flowering) Doll in the } \\
\text { center of the poster }\end{array}$ & $\begin{array}{l}\text { [...] it starts from the moment you make } \\
\text { the course, where you will find everything, } \\
\text { how it works, what will exist, what you'll } \\
\text { come across, what are you going to find } \\
\text { out, what you will learn, what are you } \\
\text { going to exercise (NTI) } \\
\text { [...] the care, everything depends on the } \\
\text { system so you can get here, to this little } \\
\text { seed can come falling apart here, get here } \\
\text { and have an improvement [...] (NT9) }\end{array}$ \\
\hline $\begin{array}{l}\text { NT1, NT4, NT6, } \\
\text { NT13 }\end{array}$ & $\begin{array}{l}\text { Deal } \\
\text { systematically } \\
\text { with } \\
\text { responsibility }\end{array}$ & $\begin{array}{l}\text { The word LIFE } \\
\text { Flowers }\end{array}$ & $\begin{array}{l}\text { Not only we should be turned to } \\
\text { pathology, and Yes to the needs that this } \\
\text { patient has, being aware of, say, a } \\
\text { particular event, the why of it (NT7) }\end{array}$ \\
\hline $\begin{array}{l}\text { NT1, NT2, NT3, } \\
\text { NT4, NT5, NT6, }\end{array}$ & $\begin{array}{l}\text { Way of providing } \\
\text { equitable and }\end{array}$ & $\begin{array}{l}\text { Dolls together of different } \\
\text { colors Word HALF }\end{array}$ & $\begin{array}{c}{[\ldots] \text { to be human with patients and with }} \\
\text { co-workers (NT2) }\end{array}$ \\
\hline $\begin{array}{c}\text { NT7, NT8, NT9, } \\
\text { NT10, NT12, } \\
\text { NT13 }\end{array}$ & quality care & Hearts Flowers & $\begin{array}{l}\text { For me the systematization of assistance } \\
\text { means planting well to scoop best (NT12) }\end{array}$ \\
\hline $\begin{array}{l}\text { NT1, NT2, NT7, } \\
\text { NT8 }\end{array}$ & $\begin{array}{l}\text { Norms and } \\
\text { techniques proper } \\
\text { of the profession }\end{array}$ & $\begin{array}{l}\text { Letters and numbers } \\
\text { Little Ducks Flowers }\end{array}$ & $\begin{array}{c}\text { Systematization, to me, starts from the } \\
\text { moment you will start the course when you } \\
\text { are assured of the profession who will } \\
\text { exercise (NT1) }\end{array}$ \\
\hline NT3, NT10 & $\begin{array}{l}\text { Professional } \\
\text { learning process }\end{array}$ & $\begin{array}{l}\text { Letters } \\
\text { Little Ducks }\end{array}$ & $\begin{array}{c}{[. . .] \text { it is through education that we can }} \\
\text { have this learning (NT3) }\end{array}$ \\
\hline
\end{tabular}




\section{Benefits of Systematization of Nursing Care}

From the concept of positivity of Systematization of Nursing Care built by NTs, multiple benefits of using this tool were elucidated: care qualification; focusing on humanescence and in the care with respect to the individuality of the users; teamwork, through the Union of professionals; parity theory-practice; strengthening the professional link-user; the Organization of care; and focus on the real needs of users.

The representations built by NT6 (Figure 1) summarise the benefits cited in unanimity by citizens of the research: to guarantee a humanescent care.

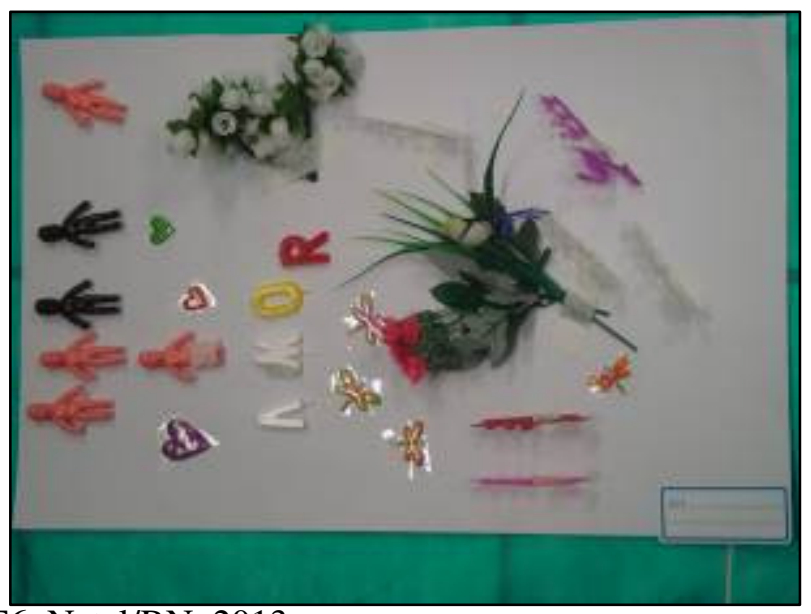

Figure 1. Poster built by NT6, Natal/RN, 2013.

Humanescent care is understood as a care that provides and enhances the expression of subjectivities of the subject, the essence of human interaction, the sensitive, disclosing, guided by humanistic interpersonal relationship. The term 'humanescent' is highlighted, so, as they understand that it is not possible to humanize what is human, but rather, seek out the expression of human essence: to become humane (CAVALCANTI, 2010).

In this perspective, it is believed that the Systematization of Nursing Care ensures the building of humanescent care, guided by respect for the individuality of the users (dolls together of different colors), by the love and care of professionals (hearts, flowers and the word LOVE) and professional dedication (ducks):

"For me the systematization of assistance means planting well to scoop best" (NT12)

"[...] to be human with patients and with coworkers" (NT2).

"[...] for there to be, really, a better work, people should have, really, sensitivity towards the patient, because it's wonderful tear a smile with a patient who has no faith, no longer have hope and you take joy for him, takes a positive energy, that's nursing" (NT13).

The qualification of interpersonal relationship was also considered an essential benefit of Systematization of Nursing Care in research that sought to meet the competencies developed in the training of nursing technicians to implement the
Systematization of Nursing Care. The participants in this study mentioned both the aspects related to the patient, the health team and highlighted the interaction in nursing staff as elements favored by the Systematization of Nursing Care implementation (CRUZ; ALMEIDA, 2010).

The understanding that the Systematization of Nursing Care organizes care, expanding the vision of the professional, which happens focusing on the real needs of users also came to prominence, with the understanding that, with the Systematization of Nursing Care, care shall be guided by a clinical reasoning:

"Not only we should be back to pathology, and, yes, to the needs those this patient has, being aware of, say, a particular event, why that, say, a pressure ulcer: because you have opened, what are we supposed to do, what to do and how to do it" (NT7).

Such a vision has been clarified in other polls that had the NTs as subjects investigated, it being understood that the Systematization of Nursing Care builds on the understanding that the professionals have about the patient's conditions, optimizing and guiding the assistance to be provided, by qualifying the care (CRUZ; ALMEIDA, 2010; LONGARAY; ALMEIDA; CEZARO, 2008).

The NTs also put in relief many problems those people experience in their professional practice, elements that deserve to be listed and rethought, since they can be translated into 
complicating of the implementation process of the Systematization of Nursing Care.

\section{Problems experienced in professional practice}

From the reflection about the practice that they live, the NTs put, deeply, multiple challenges in their profession, sometimes compromising the quality of the actions performed and, above all, the quality of life of nursing professionals (Figure 2).

"An appropriate assistance is ideal, but we know that the kind of assistance often allows us to do this task with caution" (NT7).
SALVADOR, P. T. C. O.; SANTOS, V. E. P.

Thereby, the quality healthcare was questioned, and there were highlighted the following problems that characterize its practice: the lack of material and human resources, causing the overload of work; the lack of recognition of professionals; the lack of professional humanization; the double and triple workload to which they are subjected, in virtue of the financial terms that experience; the troubled professional relationship; and the administration fails.

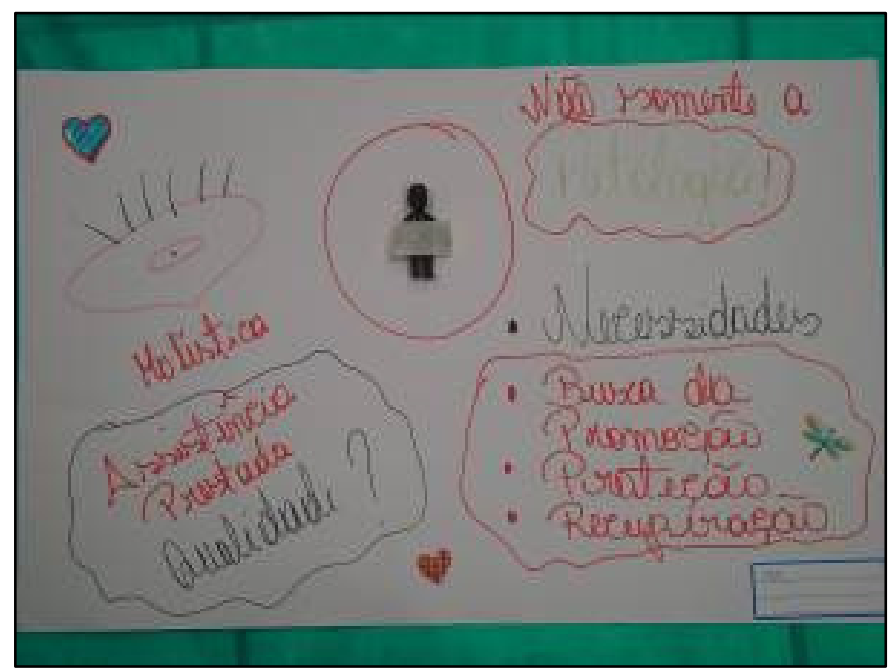

Figure 2. Poster built by NT7, Natal/RN, 2013.

Thus, with regard to the lack of recognition of professionals, several reports of NTs denounce unhealthy working conditions, which make you forget to take care of yourself:

"Actually, it was more of a rant, because often charge a lot of us technicians, but as health professionals also make us very overworked and I think this is very wrong, and I am often saddening, because often no time to care really, and Yes only medicate, because there is so much to do, many patients for one person, and our lives end up not being experienced because there's no time" (NT11).

"So either you stand quiet and works because you need, or you become unemployed. So often, we end up with ... Not here, is a teaching hospital, so we have this freedom, we will only give what we can, because, whether we like it or not, the we are students ... But, out there, we're a normal person, because they don't value us as technicians, although we love what you do and the people, who gives each here ourselves, because higher authority does not" (NT8).

"[...] to grow professionally, you have to grow up, but you have to grate" (NT1).
A study that examined the relationship between work, health and living conditions of workers found that the nursing professionals are exposed to unhealthy work environments, in the material sense and subjective, and are subjected to working conditions, with insufficient time for rest and recreation, which enhances the chances of illness and committed the care of health professionals (SPINDOLA; MARTINS, 2007).

Means the essentiality of health professionals have adequate working conditions, allowing them to attend, since, if the caregiver is unable to care for themselves, the better condition of life will and better condition will have to take care of the other and help people bring in search of selfknowledge and self-care (VIEIRA; ALVES; KAMADA, 2007).

Add the troubled labor relations, which were mainly related to the existence of professionals who don't dedicate themselves to consolidate humanescente care so coveted by the subjects of research, often by distancing the theory and practice of their actions. The NT12, reflecting on such issues, introduced the metaphor of "transparent heart": 
Ludic representations of nursing...

"[...] the transparent heart means that many people into the middle of the nursing talk, but in practice, is different, not put into practice what they say" (NT12).

\section{Needs for improvement: the way forward}

Facing the problems listed, the NTs began reflecting on the way forward to overcome them. In a way, it was exposed that the nursing professionals need to fight to chain their achievements, reflecting critically on the reality they experience:

"[...] we're covering holes, so we are also complicit with this, we are contributing to that
SALVADOR, P. T. C. O.; SANTOS, V. E. P.

happens increasingly. If the us reach and speak that I put a stop, can be better ... But, sometimes, we think of the patient, not to leave that hole, and just ended up overloading [...]" (NT10).

It is idealized that such changes will only be possible through an educational process:

"[...] it is through education that we can have this learning [...] studying would improve a lot and we'd have a better, systematic, equal for all" (NT3).

To this end, improvement needs were referred to, which are synthesized in the poster of NT1 (Figure 3).

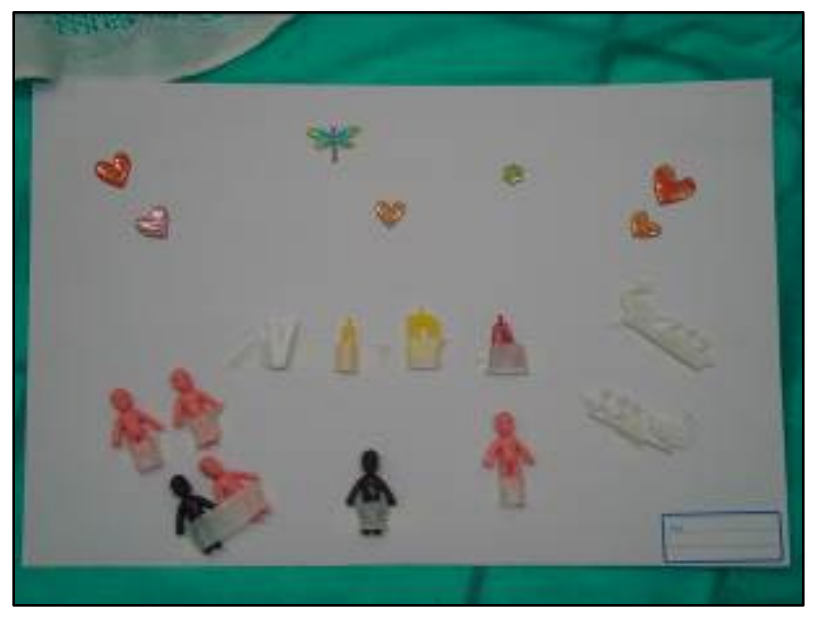

Figure 3: Poster built by NT1, Natal/RN, 2013.

The dolls together represent the Union needed by health professionals, the ducklings that there must be a multidisciplinary work and the hearts and the word LIFE clarify that professionals should have love and responsibility for exercising their profession.

It was exposed that is necessary to overcome the Cartesian model of thought, renewing ideas in pursuit of holistic focus on the real needs of users, understanding that nursing would be a continuous process of care, based on a clinical reasoning essential to consolidate effective health practices.

\section{CONCLUSIONS}

It stresses the imperativeness to integrate the process of struggle for the consolidation of Systematization of Nursing Care, being evident the need to include this subject in the curriculum of nursing technical courses, clarifying the roles and responsibilities of each member of the nursing staff.

It stands out the use of EHP as a north of realization of the focal group, which constitutes an element qualifier of the study by stimulating the expression of subjectivities and favoring the verbalization of perceptions. It is added, also, that by uniting the representation by means of scenarios, the written description of the same and the verbal sharing of buildings, the expression of playful representations have been enriched.

The EH, pegged to the focal group, was an additional element to the data collection process and the construction of knowledge, representing an innovative alternative that can contribute to the achievement of qualitative research.

It is valid noting that the results presented are the expression of a specific reality, being imperative to conduct further investigations revealing similarities and diversities regarding thoughts exposed.

It is expected, therefore, that other studies are elevations, once knowing the opinion of professional nursing components means understanding how that nursing is being built.

In addition, it aims to contribute to that, increasingly, discussing the essential interface between NTs and the Systematization of Nursing 
Care, understanding that this will only be effective when the result of reflections and actions of the entire nursing staff.

RESUMO: Objetiva-se descrever as representações lúdicas de técnicos de enfermagem acerca da Sistematização da Assistência de Enfermagem. Trata-se de um recorte dos resultados de uma investigação fenomenológica. A coleta de dados foi realizada a partir de um grupo focal com treze técnicos de enfermagem, utilizando a construção de cartazes como técnica projetiva, pautando-se nos princípios da Pedagogia Vivencial Humanescente. A análise dos dados foi realizada a partir de princípios orientadores baseados na obra de Alfred Schutz. A representação lúdica dos técnicos de enfermagem perpassou quatro eixos temáticos: conceito da Sistematização da Assistência de Enfermagem; benefícios; problemas vivenciados; e necessidades de melhoria. Conclui-se que os técnicos de enfermagem representam positivamente a Sistematização da Assistência de Enfermagem, e acreditam em sua consolidação. Destaca-se que o uso da construção de cartazes como técnica projetiva constitui um elemento qualificador do estudo, estimulando a expressão das subjetividades dos sujeitos pesquisados.

PALAVRAS-CHAVES: Educação Técnica em Enfermagem. Auxiliares de Enfermagem. Planejamento de Assistência ao Paciente. Processos de Enfermagem.

\section{REFERENCES}

BRASIL. Ministério da Saúde. Lei no 7.498, de 25 de junho de 1986. Dispõe sobre a regulamentação do exercício da Enfermagem e dá outras providências. Diário Oficial da República Federativa do Brasil. Brasília: 26 Jun 1986, Seção 1.

CAVALCANTI, K. B. Pedagogia Vivencial Humanescente: para sentir pensar os sete saberes na educação. Curitiba: Editora CRV, 2010.

CONSELHO FEDERAL DE ENFERMAGEM (COFEN). Enfermagem em Dados. Brasília: 2011. Disponível em: <http://novo.portalcofen.gov.br/planejamento-estrategico-2>. Acesso em: 18 abr. 2014.

Resolução no 358, de 15 de outubro de 2009. Dispõe sobre a Sistematização da Assistência de Enfermagem e a implementação do Processo de Enfermagem em ambientes, públicos ou privados, em que ocorre o cuidado profissional de Enfermagem, e dá outras providências. Brasília: 2009.

CRUZ, A. M. P.; ALMEIDA, M. A. Competencies in the education of Nursing Technicians to implemente the Nursing Care Systematization. Revista da Escola de Enfermagem da USP, São Paulo, v. 44, n. 4, p. 921-927, 2010.

GREJANIN, D. K. M.; PEZZO, T. H.; NASTRI, V.; SANCHES, V. P. P.; NASCIMENTO, D. D. G.;

QUEVEDO, M. P. As percepções sobre o "ser obeso" sob a ótica do paciente e dos profissionais da saúde.

Revista Brasileira de Crescimento e Desenvolvimento Humano, São Paulo, v. 17, n. 3, p. 37-47, 2007.

LONGARAY, V. K.; ALMEIDA, M. A.; CEZARO, P. Processo de Enfermagem: reflexões de auxiliares e técnicos. Texto e Contexto Enfermagem, Florianópolis, v. 17, n. 1, p. 150-157, 2008.

http://dx.doi.org/10.1590/S0104-07072008000100017

MINAYO, M. C. S. O desafio do conhecimento: pesquisa qualitativa em saúde. 12. ed. São Paulo: Hucitec, 2010.

RAMOS, L. A. R.; CARVALHO, E. C.; CANINI, S. R. M. S. Opinião de auxiliares e técnicos de enfermagem sobre a sistematização da assistência de enfermagem. Revista Eletrônica de Enfermagem, Goiânia, v. 11, n. 1, p. 39-44, 2009. Disponível em: <http://www.fen.ufg.br/revista/v11/n1/v11n1a05.htm>. Acesso em: 18 abr. 2014. 
SOUSA, F. E. M.; OLIVEIRA, E. N.; NUNES, J. M.; LOPES, R. E.; GUBERT, F. A. Percepção de estudantes de enfermagem acerca da profissão. Revista Rene, Fortaleza, v. 11, n. 4, p. 110-117, 2010.

SPINDOLA, T.; MARTINS, E. R. C. O estresse e a enfermagem - a percepção das auxiliares de enfermagem de uma instituição pública. Escola Anna Nery Revista de Enfermagem, Rio de Janeiro, v. 11, n. 2, p. 212219, 2007.

VIEIRA, A. B. D.; ALVES, E. D.; KAMADA, I. Cuidando do cuidador: percepções e concepções de auxiliares de enfermagem acerca do cuidado de si. Texto e Contexto Enfermagem, Florianópolis, v. 16, n. 1, p. 15-25, 2007. http://dx.doi.org/10.1590/s0104-07072007000100002

ZEFERINO, M. T. Mundo-vida de caminhoneiros: uma abordagem compreensiva para a enfermagem na perspectiva de Alfred Schutz. 2010. 140 f. Tese (Doutorado em Enfermagem) - Programa de Pós-Graduação em Enfermagem, Universidade Federal de Santa Catarina, Florianópolis, 2010. 